\author{
Mateusz Pękala \\ Akademia Ignatianum w Krakowie \\ https://orcid.org/0000-0002-1389-2664 \\ https://doi.org/10.15633/9788374386753.08
}

\title{
Uwarunkowania konfliktów uczelnianych i zarządzania nimi
}

Celem niniejszego opracowania ${ }^{1}$ jest analiza czynników warunkujących powstawanie, przebieg i rozwiązywanie (lub tłumienie) sytuacji konfliktowych w środowisku polskich publicznych uczelni wyższych. W części pierwszej przedstawiamy ogólne cechy uczelni publicznej, traktowanej jako specyficzny typ organizacji społecznej. Druga część artykułu poświęcona jest problematyce przyczyn, rodzajów i sposobów radzenia sobie z sytuacjami konfliktowymi w organizacjach, ze szczególnym uwzględnieniem uwarunkowań instytucji szkolnictwa wyższego. Efektem rozważań jest propozycja katalogu strategii zarządzania sporami w środowiskach uniwersyteckich oraz metod zwiększania efektywności zarządzania uczelniami w tym zakresie, przede wszystkim poprzez popularyzację mediacji.

Problematyka przyczyn i skutków sytuacji konfliktowych to jeden z głównych i najbardziej dynamicznie rozwijających się obszarów badawczych takich nauk jak teoria organizacji czy socjologia organizacji i zarządzania ${ }^{2}$. Za punkt wyjścia obieramy twierdzenie, że „pomimo obecnego poziomu rozwoju cywilizacyjnego, brak nam odpowiedniego, tj. konstruktywnego i pozytywnego, a także długofalowego podejścia do kwestii sporów międzyludzkich"3. Dotyczy to także instytucji szkolnictwa wyższego. Prezentowa-

1 Artykuł powstał w ramach projektu badawczego pt. „Wczesna diagnoza i model rozwiązania konfliktu - uniwersytet jako organizacja ucząca się (Early Case Assessment - University as a Learning Organisation)". Projekt został sfinansowany ze środków Wydziału Prawa i Administracji Uniwersytetu Jagiellońskiego. Kierownikiem projektu była dr Małgorzata Kożuch.

2 Por. M. Deutsch, Wspótpraca i rywalizacja, w: Rozwiązywanie konfliktów. Teoria ipraktyka, red. M. Deutsch, P. T. Coleman, tłum. M. Cierpisz, M. Kodura, G. Kanas, A. Kurtyka, Wydawnictwo Uniwersytetu Jagiellońskiego, Kraków 2005, s. 39.

3 A. Dyląg, J. Rosiński, Niezbędnik dla uczestników sporów, czylijakżyćw świecie konfliktów, w: Rozwiązywanie konfliktów. Teoria i praktyka, dz. cyt., s. XIII. 
ne niżej rozważania mają charakter ogólny, jednak wnioski z nich mogą być przydatne dla osób odpowiedzialnych za poprawę warunków funkcjonowania uczelni publicznych i podnoszenie jakości kształcenia.

\section{Wyzwania organizacyjne współczesnych uczelni}

Szkołę wyższą można potraktować jako specyficznego typ organizacji, stanowiącej system społeczny i funkcjonującej w oparciu o określone zasady i wartości. Uniwersytety to jedne z najstarszych form organizacyjnych w kulturze zachodniej ${ }^{4}$. Stanowią one nie tylko świadectwo dorobku cywilizacyjnego, ale są także miejscem zdobywania nowej wiedzy, przez co służą szeroko rozumianemu rozwojowi społecznemu. Wśród wartości świata nauki najczęściej wymienia się: dążenie do prawdy, postawę rzetelności i odpowiedzialności, służbę na rzecz dobra publicznego przy zachowaniu bezstronności, poszanowanie godności człowieka, promowanie dialogu i tolerancji społecznej, autonomię, legalizm czy przejrzystość działania ${ }^{5}$. Powyższy etos jest w dużym stopniu odzwierciedlony w treści preambuły oraz przepisów ogólnych aktualnie obowiązującej w Polsce ustawy Prawo o szkolnictwie wyższym i nauce ${ }^{6}$. Art. 10. ust. 1 tej ustawy stanowi zaś, że do wspólnoty uczelni należą jej pracownicy, doktoranci oraz studenci. W opracowaniach teoretycznych wymienia się natomiast następujące grupy interesariuszy instytucji akademickich:

- władze danej jednostki,

- pracownicy naukowi,

- personel administracyjny,

4 Por. K. Mizera, Kodeksy etyczne na gruncie środowisk akademickich, w: Zarzadzanie szkoła wyższa, red. J. Dworak, Wyższa Szkoła Bankowa w Gdańsku, Warszawa 2011, s. 373-374.

5 Por. J. Jóźwiak, Tradycyjne koncepcje instytucji akademickiej, w: Model zarzadzania publiczna instytucją akademicka, red. J. Woźnicki, Instytut Spraw Publicznych, Warszawa 1999, s. 18-19; B. Kożuch, Zmiany zachowań organizacyjnych pod wptywem oczekiwań interesariuszy uczelni akademickich, w: Wyzwania zarządzania jakościa w szkołach wyższych, red. T. Wawak, Wydawnictwo Uniwersytetu Jagiellońskiego, Kraków 2011, s. 62; T. Wawak, Uniwersytet na rozdrożu, w: W poszukiwaniu Uniwersytetu idealnego, red. T. Wawak, J. F. Jacko, Wydawnictwo Uniwersytetu Jagiellońskiego, Kraków 2016, s. 18; T. Oleksyn, Uniwersytet wczoraj i dziś, w: Edukacja uniwersytecka a oczekiwania społeczne, red. E. Okoń-Horodyńska, J. F. Jacko, I. Maciejowska, Wydawnictwo Uniwersytetu Jagiellońskiego, Kraków 2017, s. 57.

6 Ustawa z dnia 20 lipca 2018 r. Prawo o szkolnictwie wyższym i nauce (Dz. U. z 2018 r. poz. $1668 \mathrm{z}$ późn. zm.), http://prawo.sejm.gov.pl/isap.nsf/download.xsp/WDU20180001668/U/ D20181668Lj.pdf (dostęp: 27.08.2020). 
- studenci i doktoranci,

- słuchacze i absolwenci,

- pracodawcy i interesariusze zewnętrzni,

- instytucje władzy samorządowej i centralnej7.

Społeczność uczelni jest środowiskiem bardzo zróżnicowanym, każda z grup posiada własne zasady działania oraz interesy. Co więcej, podsystemami społecznymi (subkulturami organizacyjnymi) są nie tylko podstawowe jednostki organizacyjne (rektorat, wydziały), ale także np. biblioteki, szkoły języków obcych, domy studenckie (często określane mianem „miasteczek akademickich"), infrastruktura sportowa oraz inne jednostki międzywydziałowe. Zróżnicowanie wydziałów jest zaś skorelowane ze specyfiką badań i kształcenia $\mathrm{w}$ ramach różnorodnych dziedzin nauki. Publicznymi instytucjami szkolnictwa wyższego w Polsce najczęściej są organizacje:

- duże lub bardzo duże,

- posiadające znaczną autonomię,

- ze strukturą opartą na wyraźnym podziale hierarchicznym,

- w wysokim stopniu zbiurokratyzowane,

- dążące do komercjalizacji, a w konsekwencji silnie konkurujące z innymi instytucjami edukacyjnymi,

- coraz bardziej zorientowane na wymierne efekty praktyczne, kosztem analiz teoretycznych ${ }^{8}$.

Rytm życia każdej uczelni wyznaczany jest przez pewne cykliczne wydarzenia, takie jak np. inauguracja roku akademickiego, sesje egzaminacyjne, obrony prac dyplomowych, wydarzenia naukowe czy juwenalia. Specyfika funkcjonowania każdej instytucji edukacyjnej polega na naturalnej rotacji studentów, którzy po zakończeniu określonego cyklu kształcenia najczęściej tracą z nią kontakt. Na sposób zarządzania uczelniami publicznymi wpływa także zasada kadencyjności władz, która może stanowić potencjalną barierę dla konsekwentnego sterowania strategicznym rozwojem uczelni.

Oprócz sporego „bagażu” tradycji i zwyczajów środowiska akademickiego działalność uczelni publicznych jest w znaczny sposób zdeterminowana przepisami prawnymi, i to nie tylko tymi dotyczącymi struktury, zasad

7 Por. Ł. Sułkowski, Kultura akademicka. Koniec utopii?, Wydawnictwo Naukowe PWN, Warszawa 2016, s. 59.

8 Por. M. Czapski, Mediacja w sporach akademickich, w: Mediacje. Teoria i praktyka, red. E. Gmurzyńska, R. Morek, Wolters Kluwer, Warszawa 2009, s. 282; B. Kożuch, Zmiany zachowań organizacyjnych..., dz. cyt., s. 56; Ł. Sułkowski, Kultura akademicka..., dz. cyt., s. 17-20. 
działania czy wymogów odnośnie do procesu kształcenia, ale również np. prawem administracyjnym czy prawem zamówień publicznych: „Większa biurokracja $\mathrm{w}$ uczelniach publicznych traktowana jest jako efekt uboczny zarządzania opartego na hierarchii. (...) Stąd skłonność do tworzenia niezliczonych dokumentów, do sposobów załatwiania spraw w praktyce oznaczających irytację osób korzystających z usług edukacyjnych, spowodowaną licznymi opóźnieniami oraz brakiem zauważalnego postępu w dostosowywaniu funkcjonowania organizacji do potrzeb publicznych" ${ }^{\text {. Efektywność }}$ uczelni publicznych ograniczają także problemy finansowe, które często mają charakter chroniczny ${ }^{10}$.

Źródłem napięć może być konieczność łączenia przez uniwersytety działalności typowo badawczej i rozwojowej z działalnością dydaktyczną, co ma swoje konsekwencje - np. dla polityki kadrowej, która powinna być (a nie zawsze jest) przejrzysta i oparta na kryteriach merytorycznych ${ }^{11}$. Z kolei z punktu widzenia „odbiorców” usług edukacyjnych na pierwszy plan wysuwa się masowy charakter kształcenia na wielu kierunkach. W niektórych przypadkach na jednym roku studiuje nawet kilkaset osób. Dopiero niedawno wprowadzone wymogi określają wymagane proporcje pomiędzy liczbą studentów a liczbą wykładowców. Orientacja rynkowa skutkuje tym, że misja społeczna uniwersytetów i przyświecające edukacji cele „wyższe” niejednokrotnie wypierane są przez nastawienie na „produkowanie” absolwentów, czyli jak najszybsze przekazywanie im umiejętności praktycznych, co odbywa się często kosztem zaplecza teoretycznego (filozoficznego, etycznego, społecznego itp.) danej dziedziny. Studenci traktowani są dziś jako nabywcy usług edukacyjnych, których preferencje (np. ilość kosztem jakości) decydują o organizacji procesu kształcenia.

Wśród problemów organizacyjnych uczelni publicznych najczęściej wymienia się brak decyzyjności i konsekwencji w działaniu oraz liczne bariery komunikacyjne, związane z zakłóceniami w przepływie informacji pomiędzy i wewnątrz jednostek organizacyjnych ${ }^{12}$. Dotychczasowe badania potwierdzają, że dosyć łatwo znaleźć przykłady złej organizacji pracy nauczycieli

\footnotetext{
9 B. Kożuch, Zmiany zachowań organizacyjnych..., dz. cyt., s. 54 .

10 Por. Ł. Sułkowski, Kultura akademicka..., dz. cyt., s. 17-2o.

11 Por. B. Kożuch, Zmiany zachowań organizacyjnych..., dz. cyt., s. 54 .

Por. B. Kożuch, Zmiany zachowań organizacyjnych..., dz. cyt., s. 54 .
} 
akademickich i jednostek administracyjnych ${ }^{13}$. Problemy ze sprawnym przepływem informacji są jedną z głównych przyczyn nieporozumień i konfliktów w każdej organizacji, a sytuacji z pewnością nie ułatwiają okoliczności, takie jak np. zbyt liczne grupy na zajęciach ćwiczeniowych, zbyt mała liczba godzin dydaktycznych w stosunku do zakresu treści merytorycznych, źle ułożone harmonogramy czy niesprzyjające warunki prowadzenia wykładów i ćwiczeń (problemy lokalowe, brak wyposażenia itp.). Niestety na wielu uniwersytetach tego typu sytuacje nie należą do rzadkości ${ }^{14}$.

Od lat 9o. XX wieku polskie szkolnictwo wyższe podlegało bardzo licznym i daleko idącym zmianom. Niezależnie od zmieniających się standardów międzynarodowych i przepisów krajowych, uczelnie - tak jak i wszystkie organizacje - muszą być gotowe do odpowiedniego reagowania na procesy zachodzące w ich otoczeniu, nowe potrzeby i oczekiwania społeczne, a także na turbulencje ekonomiczne ${ }^{15}$. Funkcjonowanie uniwersytetów powinno być dostosowane nie tylko do zmian pokoleniowych (aktualnie studentami są głównie przedstawiciele tzw. pokolenia milenialsów), ale także do specyfiki konkretnych roczników, ponieważ innego podejścia wymagają studenci pierwszego roku, a innego osoby, które za kilka miesięcy zdobędą tytuł magistra ${ }^{16}$.

Najbardziej ogólna typologia sposobów zarządzania uczelnią obejmuje modele: kolegium (władzę mają pracownicy, sami określający zakres uprawnień i obowiązków swoich zwierzchników, a na tych ostatnich wybierani są częściej liderzy niż menedżerowie), biurokracji (główną rolę odgrywają jednostki administracyjne, dbające przede wszystkim o spełnienie wymagań prawnych i finansowych, a rola władzy sprowadza się tu do uzgadniania różnorodnych interesów wewnętrznych), korporacji (władza zorientowana jest w dużej mierze na reprezentowanie organizacji na zewnątrz) oraz przedsiębiorstwa (władza uczelni spełnia zadania analogiczne do zarządu prywatnej

Por. A. Kisiel, Bariery komunikacyjne na uczelni akademickiej oraz sposoby ich pokonywania, w: Wyzwania zarządzania jakościq̨..., dz. cyt., s. 166. stytucją akademicka, red. J. Woźnicki, Instytut Spraw Publicznych, Warszawa 1999, s. 18-19; M. Geryk, Przywództwo na trudne czasy, czyli rzecz o odpowiedzialnych menedżerach uczelni, w: Zarzqdzanie szkoła wyższa, red. J. Dworak, Wyższa Szkoła Bankowa w Gdańsku, Warszawa 2013, s. 47; T. Wawak, Uniwersytet na rozdrożu, dz. cyt., s. 18.

16 Por. T. Marcysiak, Zarządzanie retencją studentów - perspektywa socjologiczna, w: Zarządzanie szkoła wyższa, red. J. Dworak, Wyższa Szkoła Bankowa w Gdańsku, Warszawa 2013, s. 30. 
firmy $)^{17}$. Dla każdego z tych ujęć ważne jest, aby władze uczelni miały zdolność budowania relacji, przełamywania barier komunikacyjnych, negocjowania i skutecznego rozwiązywania różnego rodzaju napięć wewnętrznych pomiędzy poszczególnymi elementami organizacji. Oprócz wspomnianej wyżej komercjalizacji do aktualnych zagrożeń etosu środowiska akademickiego zaliczyć można również np. brak troski o dobro wspólne, nadmierny wpływ interesów partykularnych czy łamanie norm etycznych ${ }^{18}$. Przynajmniej niektóre z tych zagrożeń mogą być minimalizowane przez stosowanie skutecznych metod rozwiązywania konfliktów.

Tadeusz Wawak słusznie zauważa, że „władze uczelni powinny eliminować wszelkie pojawiające się patologie, w tym przeciwdziałać funkcjonowaniu grup interesów (ugrupowań politycznych, wyznań, myślących inaczej, różnych koterii) oddziałujących na funkcjonowanie uczelni oraz uniemożliwiać działania wewnętrznych grup nacisku i ingerencję zewnętrzną różnych instytucji” ${ }^{\prime 19}$. Ten sam autor, podkreślając potrzebę racjonalnego wprowadzania zmian w polskim szkolnictwie wyższym, powołuje się na ogólną koncepcję dojrzałości organizacyjnej uniwersytetu. Dwa najwyższe stopnie tej dojrzałości określane są jako development (nastawienie na rozwój, podnoszenie jakości zarządzania poprzez audyty, szkolenia i realizację działań zapobiegawczych) oraz excellence (dążenie do doskonałości, realizacja idei zrównoważonego uniwersytetu przyszłości) ${ }^{20}$. Polskie uczelnie dopiero zaczynają realizować te standardy w praktyce. Tymczasem nowoczesna akademia powinna posiadać kluczowe zdolności niezbędne do budowania przewagi konkurencyjnej w turbulentnym otoczeniu, a chodzi tu m.in. o: spójność i konsekwencję w działaniu; błyskotliwość w obserwacji otoczenia i wyciąganiu wniosków; zwinność - zdolność do adaptacji do nowych warunków; innowacyjność - tworzenie nowych idei lub kreowanie nowych wartości przez łączenie już istniejących elementów organizacji; szybkość w reagowaniu na potrzeby klienta i rynku; otwartość na nowe technologie ${ }^{21}$. Przede wszystkim chodzi zaś o to, aby osoby kierujące instytucjami szkolnictwa wyższego nie ograniczały się jedynie do administrowania, ale by potrafiły

17 Por. J. Jóźwiak, Tradycyjne koncepcje instytucji..., dz. cyt., s. 20-21.

18 Por. J. Jóźwiak, Tradycyjne koncepcje instytucji..., dz. cyt., s. 18-19.

19 T. Wawak, Uniwersytet na rozdrożu, dz. cyt., s. 26.

20 Por. T. Wawak, Uniwersytet na rozdrożu, dz. cyt., s. 16-17.

21 Por. T. Maliszewski, Jak wykreować sukces uczelni. Budowanie przewagi konkurencyjnej na rynku edukacyjnym, Wolters Kluwer, Warszawa 2015, s. 33. 
rzeczywiście skutecznie zarządzać w myśl podejścia menedżerskiego, czyli w sposób proaktywny i innowacyjny ${ }^{22}$.

Przedsiębiorcze zarządzanie instytucją badawczo-edukacyjną wymaga dzisiaj elastyczności rozumianej jako zdolność do szybkiego wprowadzania zmian w strukturze organizacyjnej, zmienności hierarchii oraz podziału zadań, a także umiejętności w zakresie tworzenia dogodnych warunków do pracy zespołowej ${ }^{23}$. Dlatego osoby, które chcą w sposób odpowiedzialny sprawować przywództwo organizacyjne w uniwersytetach powinny dzisiaj - oprócz klasycznych „twardych” umiejętności menedżerskich - posiadać również „szeroką wiedzę z zakresu orientacji społecznej, wzbogaconą o empatyczne rozumienie potrzeb i oczekiwań interesariuszy. Istotna jest zmiana mentalna i pełna gotowość do działania w sposób otwarty i transparentny"24. Dużego znaczenia w tym kontekście nabiera zdolność odpowiedniego reagowania na sytuacje konfliktowe, czemu poświęcimy kolejny punkt rozważań.

\section{Przyczyny i rodzaje konfliktów organizacyjnych}

$\mathrm{W}$ naukach społecznych formułowanych jest wiele różnorodnych definicji konfliktu $^{25}$. Na potrzeby niniejszego opracowania wystarczy przyjąć, że jest to proces obejmujący „działanie przynajmniej dwupodmiotowe, w którym jeden z podmiotów przeszkadza drugiemu w osiągnięciu jakiegoś celu, przy czym sprzeczności interesów występują obiektywnie lub mogą być tylko wyobrażone" ${ }^{26}$. Konfliktem uczelnianym będzie zaś taka sprzeczność, której stronami są członkowie społeczności danej instytucji akademickiej. Nieporozumienia nie są niczym wyjątkowym, zdarzają się przecież w każdym środowisku społecznym: „Konflikty w organizacji są nieuniknione; występują niezależnie od sprawności i kwalifikacji kierowników. Dlatego też, wymieniając klasyczne kierownicze (planowanie, organizowanie, motywowanie, kontrolowanie), niekiedy dodaje się umiejętności kierowania konfliktami.

22

23

24

\footnotetext{
Por. T. Wawak, Uniwersytet na rozdrożu, dz. cyt., s. 25.

Por. Ł. Sułkowski, Kultura akademicka..., dz. cyt., s. 23.

M. Geryk, Przywództwo na trudne czasy, czyli rzecz o odpowiedzialnych menedżerach uczelni, w: Zarządzanie szkoła wyższq, red. J. Dworak, Wyższa Szkoła Bankowa w Gdańsku, Warszawa 2013, s. 43 .

5 Szerzej na ten temat: A. Wajda, Organizacja i zarzadzanie, Polskie Wydawnictwa Ekonomiczne, Warszawa 2003, s. 242-244.

E. Masłyk-Musiał, Społeczeństwo i organizacje. Socjologia organizacji izarządzania, Wydawnictwo UMCS, Lublin 1996, s. 137.
} 
Oznacza to, że kierownik powinien opanować sztukę kierowania konfliktem i zdawać sobie sprawę, że jest to zjawisko nieuchronne, a często nawet pożą-

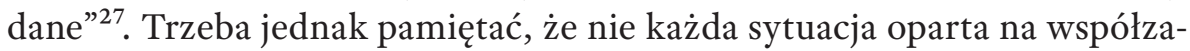
wodnictwie musi prowadzić do wybuchu konfliktu ${ }^{28}$.

Konflikty są na stałe wpisane w życie każdej organizacji, a do ich najczęstszych przyczyn należą: dynamika świata organizacyjnego, nadmierne wymagania wobec członków organizacji i inne błędy kierownicze. Na powstawanie i intensywność konfliktów organizacyjnych mogą wypływać takie czynniki jak: otoczenie organizacji, strategia, technologia, struktura społeczna organizacji, kultura organizacyjna oraz struktura fizyczna danego podmiotu ${ }^{29}$. Niezgoda może być także skutkiem z „aspiracji i ambicji ludzkich, z chęci dominacji, złości i zawiści”30. Przyczyny konfliktów można zaś generalnie podzielić na:

- osobowościowe (związane z cechami indywidualnymi członków organizacji),

- kulturowe (związane z poglądami, postawami, normami i wartościami członków),

- strukturalne (związane np. z hierarchią władzy lub podziałem pracy),

- funkcjonalne (związane z przebiegiem procesów i interakcji jednostek i grup) $)^{31}$.

Powstawaniu i rozwojowi antagonizmów sprzyjają przykładowo: uprzywilejowanie jednego podmiotu (lub grupy) względem innych; szczupłość zasobów (materialnych i niematerialnych); wspólne zasoby; niezgodność celów na poziomie operacyjnym; współzależność zadań; źle określone kryteria oceniania osiągnięć i przyznawania nagród ${ }^{32}$. Dodać tu można także przypadki braku lub niejasności norm organizacyjnych, „naturalny” opór ludzi wobec zmian, a także niezgodności o charakterze osobowościowym pomiędzy członkami danej społeczności ${ }^{33}$. Nie bez znaczenia jest tu doświadczenie

27 A. Wajda, Organizacja izarzadzanie, dz. cyt., s. 246.

28 Por. A. Wajda, Organizacja i zarzadzanie, dz. cyt., s. 246.

29 Por. M.J. Hatch, Teoria organizacji, tłum. P. Łuków, Wydawnictwo Naukowe PWN, Warszawa 2002, s. 309-310.

30 E. Masłyk-Musiał, Społeczeństwo i organizacje..., dz. cyt., s. 137.

31 Por. Cz. Sikorski, Jezyk konfliktu. Kultura komunikacji społecznej w organizacji, Wydawnictwo C.H. Beck, Warszawa 2005, s. 39; A. Wajda, Organizacja izarzadzanie, dz. cyt., 254.

32 Por. M.J. Hatch, Teoria organizacji, dz. cyt., s. 298, 305-309; A. Wajda, Organizacja izarzadzanie, dz. cyt., s. 252-253.

33 Por. A. Wajda, Organizacja izarzadzanie, dz. cyt., s. 253; A. Jachnis, Psychologia organizacji. Kluczowe zagadnienia, Difin, Warszawa 2008, s. 189-19o. 
i stopień integracji pracowników: „Możliwość występowania konfliktów jest największa wtedy, kiedy członkowie organizacji są młodzi, a współczynnik fluktuacji jest wysoki”" ${ }^{34}$. Na dynamikę i efekty konfliktów wpływa także poziom wiedzy merytorycznej stron, a także poziom ich umiejętności i woli współpracy w rozwiązaniu danego problemu ${ }^{35}$.

Pod względem podmiotowym możemy mieć do czynienia ze sporami: wewnętrznymi (intrapersonalnymi), interpersonalnymi (między jednostkami - osobami fizycznymi), między jednostką a grupą, między grupami funkcjonującymi w ramach tej samej organizacji oraz między dwiema (lub więcej) organizacjami ${ }^{36}$. W kontekście instytucji szkolnictwa wyższego na pierwszy plan wysuwa się wspomniane wyżej spore zróżnicowanie wewnętrzne, ponieważ „mamy tu do czynienia nie tylko z ludźmi występującymi w odmiennych rolach w środowisku akademickim, ale także charakteryzującymi się stosunkowo dużym indywidualizmem, pochodzącymi z bardzo różnych środowisk społecznych i skłonnymi do eksperymentowania z przyjętymi konwencjami i granicami dopuszczalnych zachowań"37. Z punktu widzenia naszych rozważań potencjalnymi stronami konfliktów uczelnianych są:

- władze danej instytucji (na poziomie rektora, dziekana, kierownika instytutu, kierownika katedry);

- pracownicy naukowo-dydaktyczni (niezależnie od formy zatrudnienia);

- personel administracyjny (zarówno ten zajmujący się sprawami formalnymi, jak i ten dbający o obsługę infrastruktury i zapewnienie warunków technicznych);

- studenci i doktoranci oraz słuchacze.

Interesują nas zarówno nieporozumienia wewnątrz każdej z tych grup, jak i pomiędzy co najmniej dwiema z nich. Przyczyn konfliktów międzygrupowych w dużych organizacjach najczęściej upatruje się w: starciach na tle hierarchii i stosunków podległości służbowej (np. ucieczka od odpowiedzialności, hamowanie oddolnych inicjatyw); rozbieżności interesów grup w związku ze zróżnicowaniem ich zadań; odmienności poglądów między

34 A. Wajda, Organizacja izarzadzanie, dz. cyt., s. 253.

35 Por. E. Masłyk-Musiał, Społeczeństwo i organizacje..., dz. cyt., 142.

36 Por. A. Wajda, Organizacja i zarzadzanie, dz. cyt., s. 248.

37 M. Czapski, Mediacja w sporach akademickich, w: Mediacje. Teoria i praktyka, red. E. Gmurzyńska, R. Morek, Wolters Kluwer, Warszawa 2009, s. 277. 
linią a sztabem; negatywnie rozumianej rywalizacji między grupami formalnymi i nieformalnymi ${ }^{38}$.

Samo środowisko studenckie nie jest jednolite, a szeroko rozumiany proces edukacyjny (grupy ćwiczeniowe, wspólne mieszkanie w akademiku) wymusza częste interakcje. Tymczasem wśród studentów „pojawiają się duże różnice, wynikające $\mathrm{z}$ odmienności kulturowych, wychowania $\mathrm{w}$ różnych środowiskach czy wyznawania innych wartości przekazanych w domu rodzinnym”, a ponadto „na niektórych kierunkach ścieranie się racji i poglądów oraz wymiana zdań wpisane są w istotę studiowania"39. Co więcej, studenci pierwszych lat często są zdezorientowani, nie mają doświadczenia w funkcjonowaniu w środowisku uczelnianym. $Z$ kolei potencjalnie najbardziej konfliktogenne interakcje pomiędzy studentami a wykładowcami związane są z procesem egzaminowania, natomiast powszechne na polskich uczelniach problemy organizacyjne są podłożem antagonizmów, których uczestnikiem staje się także personel administracyjny ${ }^{40}$. Rzeczywiste przyczyny i skutki antagonizmów często stanowią w organizacjach tematy tabu i są „tajemnicami poliszynela”. Pod tym względem formy przebiegu konfliktów można podzielić na jawne (np. skargi, zażalenia, strajki) i ukryte (np. rozgrywki personalne, wzmożona absencja, plotki, anonimy) ${ }^{41}$.

W świetle charakterystyki uczelni jako specyficznego typu organizacji okazuje się, że zapobieganie konfliktom w tym środowisku nie jest zadaniem łatwym: „Ogólnie można stwierdzić, że im struktura i kultura organizacji są «sztywniejsze», tym mniejsze jest prawdopodobieństwo korzystnego rozwiązania konfliktu. Nierozwiązany konflikt może również ujemnie wpłynąć na organizację o strukturze niesformalizowanej, w której poszczególne komórki są od siebie uzależnione dopływem informacji” ${ }^{42}$. Dodajmy, że nieskuteczne zarządzanie dużymi instytucjami sprzyja nie tylko obniżeniu poziomu motywacji pracowników i klientów, ale stanowi także podłoże dla bardziej poważnych zjawisk patologicznych. Przykładowo, wśród czynników ułatwiających mobbing wymienia się: złą organizację pracy, słabe kierownictwo, nepotyzm, zbytnią hierarchiczność struktury, konformizm otoczenia,

\footnotetext{
38 Por. Cz. Sikorski, Jezzyk konfliktu..., dz. cyt., s. 45.

39 M. Czapski, Mediacja w sporach akademickich, dz. cyt., s. 276.

40 Por. M. Czapski, Mediacja w sporach akademickich, dz. cyt., s. 278-279.

41 Por. M.J. Hatch, Teoria organizacji, dz. cyt., s. 298; A. Wajda, Organizacja izarządzanie, dz. cyt., S. 249.

42 A. Wajda, Organizacja i zarzadzanie, dz. cyt., s. 256-257.
} 
nieprzejrzystość ocen, awansów, konkursów, nadużywanie władzy, a także brak mechanizmów rozwiązywania konfliktów, w tym brak mediatorów ${ }^{43}$. Skoro nieporozumień i napięć nie da się całkowicie wyeliminować z życia uniwersytetu, należy wypracowywać odpowiednie sposoby reagowania na tego typu sytuacje.

\section{Strategie zarządzania konfliktami organizacyjnymi}

Badacze społeczni i praktycy zarządzania tradycyjnie postrzegali konflikty negatywnie. Klasyczne teorie społeczne i menedżerskie traktują antagonizm organizacyjny jako objaw dysfunkcji. I rzeczywiście, negatywnie rozumiana rywalizacja może mieć wiele destrukcyjnych skutków, takich jak np. dezorganizacja, powstawanie podziałów, obniżenie morale pracowników czy zastępowanie działań racjonalnych przez nieracjonalne ${ }^{44}$. Nie ma jednak takiej organizacji, w której spory by się nie pojawiały: „Sprzeczki w życiu występują nagminnie i nie możemy przed nimi uciec. Nie stanowią one jednak zagrożenia, czyli nie naruszają stosunków interpersonalnych, nie powodują zakłóceń w pracy zespołu oraz nie utrudniają zaspokajania ludzkich potrzeb. Często jednak na pozór drobne sprzeczki z upływem czasu mogą się kumulować i przerodzić w starcia" 45 .

Współcześnie konflikty są - zarówno przez teoretyków, jak i przez praktyków - traktowane jako zjawiska „naturalne, konieczne i warte kierowania"46. Podstawą dla takiego podejścia jest dostrzeżenie, że - oprócz skutków negatywnych - pozytywnie rozumiana, odpowiednio organizowana i konstruktywnie zakończona konkurencja wewnątrz organizacji może przynieść wiele korzyści. Przykładowo, ujawnienie konfliktu może zwrócić uwagę decydentów na wcześniej ignorowane problemy, może stanowić motywację członków organizacji do zrozumienia odmiennego stanowiska, może być przyczynkiem do opracowywania nowych pomysłów i wprowadzania zmian usprawniających działanie, a skutecznie pokonane kryzysy zwiększają

43 Por. J. Wieczorek, Mediator akademicki jako przeciwdziałanie mobbingowi w środowisku akademickim, Niezależne Forum Akademickie, Kraków 2009, s. 29.

44 Por. A. Wajda, Organizacja izarządzanie, dz.cyt., s. 257-258, A. Jachnis, Psychologia organizacji..., dz. cyt., s. 186.

45 A. Wajda, Organizacja i zarzadzanie, dz. cyt., s. 256.

46 E. Masłyk-Musiał, Społeczeństwo i organizacje..., dz. cyt., s. 136; Por. także: M. J. Hatch, Teoria organizacji, dz. cyt., s. 299-301; A. Wajda, Organizacja izarządzanie, dz. cyt., s. 246-247. 
zaangażowanie i lojalność pracowników ${ }^{47}$. Zestaw strategii ułatwiających świadome i racjonalne dążenie kierowników do minimalizowania negatywnych i maksymalizowania pozytywnych skutków sporów organizacyjnych jest analizowany w ramach koncepcji zwanej zarządzaniem sytuacjami konfliktowymi (conflict management), przy czym „przez zarządzanie konfliktem rozumie się sprawowanie nad nim kontroli, aby nie był destrukcyjny"48. Chodzi o ograniczenie rywalizacji, opanowanie emocji i skuteczne oraz kreatywne reagowanie na kryzysy ${ }^{49}$. Innymi słowy, sprawny menedżer powinien starać się działać tak, „aby energię i twórczy wysiłek ukierunkować na rozwiązanie problemu, a nie na wzajemne zmagania”, zmieniać orientację stron z opartej na wizji: „my przeciw wam” na orientację „my przeciw problemowi" ${ }^{50}$. W praktyce najczęstsza reakcja kierownika na wybuch konfliktu $\mathrm{w}$ zespole to zmiana stylu przywództwa z partycypacyjnego na autokratyczny, czyli wzmożenie działań kontrolnych i przejście na „ręczne sterowanie” pracą podwładnych ${ }^{51}$. Nie zawsze jest to jednak najlepsze rozwiązanie, ponieważ objęcie przez menedżera roli „policjanta” nie sprawdza się w perspektywie długoterminowej. Zarządzanie konfliktem powinno być elastyczne: „Podjęcie zdecydowanych działań przez kierownika często definitywnie zakończy konflikt. Jest to jednak metoda nie do końca właściwa, gdyż wraz z tym tłumi się pomysły warte przeanalizowania, tworzy atmosferę nieufności lub zniechęcenia w realizacji zadań. $Z$ kolei tolerowanie konfliktu podsyca niezgodę, która tworzy niesprzyjającą atmosferę współpracy w zespole. Kierownik musi mieć rozległą wiedzę w tym zakresie, musi być przygotowany na zajmowanie się konfliktem, gdyż - jak uczy doświadczenie - szkodliwy, negatywny konflikt łatwiej rozwiązać lub przynajmniej ograniczyć na wcześniejszym etapie jego zaistnienia”52. Warto dodać, że kierownik „powinien zawsze szukać takich możliwości, które kreowałyby rozwiązania «wygrany-wygrany». W praktyce osiągnięcie satysfakcji przez obie strony jest często niemożliwe, jednak postępowanie kierownika powinno być takie, aby uniknąć rozwiązania, w którym obydwie strony przegrywają" ${ }^{53}$. W innym cyt., s. 257.

48 A. Jachnis, Psychologia organizacji..., dz. cyt., s. 192.

49 Por. M. Deutsch, Wspótpraca i rywalizacja, dz. cyt., s. 27.

50 Por. Cz. Sikorski, Język konfliktu..., dz. cyt., s. 41-42.

51 Por. A. Jachnis, Psychologia organizacji..., dz. cyt., s. 191.

52 A. Wajda, Organizacja i zarządzanie, dz. cyt., s. 255.

53 A. Wajda, Organizacja i zarzadzanie, dz. cyt., s. 255. 
podręczniku z zakresu zarządzana przeczytamy podobne wskazówki: „Dla sprawnego funkcjonowania organizacji szczególnie niekorzystne jest występowanie gier typu wygrał-przegrał (antagonistyczne). Żeby nie było w organizacji ludzi o samopoczuciu «pokonanych», należy troszczyć się w niej o zbiorową akceptację celów, zaangażowanie w realizację zadań i budowanie zespołów sieciowych wzajemnie wspierających się w realizacji misji firmy. Kto bowiem lubi być pokonany?"54

Zarządzanie konfliktami w organizacjach nie jest łatwe, ponieważ sytuacje społeczne są na tyle różnorodne, a na dynamikę sporów wpływa tak wiele czynników, że trudno wskazać uniwersalne zasady, które zapewnią stuprocentową skuteczność. Nie istnieją w tym zakresie żadne automatyzmy, a konstruktywne rozwiązanie nie zawsze jest możliwe do osiągnięcia - z różnych, czasami obiektywnych, a czasami subiektywnych powodów. Nawet dobra wola wyrażona przez wszystkie strony nie zawsze jest gwarancją końcowego sukcesu ${ }^{55}$. Na pewno należy unikać zarówno blokowania informacji, jak i ich nadmiaru; rozmyślnego przekazywania niejednoznacznych komunikatów, a także niejasnych kryteriów oceny działań lub wyników podwładnych. Do sposobów zapobiegania eskalacji należą zaś np. fizyczne rozdzielenie skłóconych osób, zwiększenie dostępnych zasobów czy wprowadzenie rotacji stanowisk ${ }^{56}$. Nie wszystkie $\mathrm{z}$ tych rozwiązań będą jednak skuteczne w perspektywie długoterminowej.

Zapobieganie powstawaniu i rozwojowi nieporozumień sprzyja taka polityka kierowania organizacją, która jest oparta na promowaniu odpowiednich postaw etycznych wobec antagonizmów ${ }^{57}$. Budowanie instytucjonalnej kultury etycznego konfliktu polega na wprowadzaniu takich zasad jak: indywidualizm, poczucie sprawiedliwości, podejście empatyczne i gotowość do poszukiwania kompromisu ${ }^{58}$. Wśród wskazówek dotyczących prowadzenia negocjacji organizacyjnych w sposób etyczny znajdziemy zaś następujące postulaty: nie grozić użyciem siły, dotrzymywać słowa, okazywać chęć do kompromisów, szanować autorytety społeczne, szanować sprawowaną

54 E. Masłyk-Musiał, Społeczeństwo i organizacje..., dz. cyt., 141.

55 Por. Cz. Sikorski, Jezzyk konfliktu..., dz. cyt., s. 41-42; M. Deutsch, Wspótpraca i rywalizacja, dz. cyt., s. 30 .

56 Por. M.J. Hatch, Teoria organizacji, dz. cyt., s. 302.

57 Por. Cz. Sikorski, Język konfliktu..., dz. cyt., s. 62-75.

58 Por. Cz. Sikorski, Jezzyk konfliktu..., dz. cyt., s. 70. 
przez siebie funkcję $e^{59}$. Morton Deutsch formułuje m.in. następujące wskazówki służące skutecznemu zarządzaniu konfliktem: poszukuj wspólnych interesów, skoncentruj się na problemie i powstrzymaj się od ataków personalnych, staraj się zrozumieć cudze poglądy, buduj porozumienie na pomysłach innych osób, doceniaj drugą stronę, ogranicz i kontroluj wyrażanie swoich negatywnych odczuć, bądź odpowiedzialny za konsekwencje swoich czynów i słów, bądź gotowy wybaczyć, bądź wyczulony na uzasadnione potrzeby innych, bądź uczciwy ${ }^{60}$. Ostatnia z jego rad brzmi natomiast: „Przez cały czas bądź osobą moralną - czyli osobą, która jest troskliwa i sprawiedliwa; uważaj innych za członków swojej moralnej społeczności - czyli za osoby, które zasługują na troskę i sprawiedliwość” ${ }^{61}$. Warto zwrócić uwagę także na wskazówki dotyczące tworzenia warunków skutecznej współpracy w organizacji ${ }^{62}$, wartości, jakimi należy się kierować w konstruktywnym rozwiązywaniu nieporozumień ${ }^{63}$, a także strategie przydatne w stosowaniu podejścia kreatywnego do zarządzania konfliktami ${ }^{64}$. Jeśli chodzi o dynamikę interwencji, najczęściej postuluje się etapowe przechodzenie od rozwiązań nieformalnych i prywatnych do rozwiązań opartych na niewiążących lub wiążących decyzjach podmiotu trzeciego, przy czym zastosowanie metod opartych na przymusie i uległości powinno mieć miejsce jedynie jako ostateczność, gdy inne, „łagodniejsze” metody nie przyniosą rezultatu ${ }^{65}$.

\section{Wnioski}

Dokładny opis wszystkich strategii zarządzania konfliktem organizacyjnym i ich adaptacja do specyfiki instytucji szkolnictwa wyższego wykracza poza ramy niniejszego opracowania. Naszym celem jest zwrócenie uwagi na konieczność prowadzenia dalszych analiz modeli teoretycznych i podjęcia badań empirycznych na temat praktyki funkcjonowania polskich uczelni, aby zweryfikować, czy i jaka koncepcja zarządzania konfliktami jest w nich

59 Por. E. Masłyk-Musiał, Społeczeństwo i organizacje..., dz. cyt., s. 145.

6o Por. M. Deutsch, Wspótpraca i rywalizacja, dz. cyt., s. 33.

61 M. Deutsch, Wspótpraca i rywalizacja, dz. cyt., s. 33.

62 Por. M. Deutsch, Wspótpraca i rywalizacja, dz. cyt., s. 25-26.

63 Por. M. Deutsch, Wspótpraca i rywalizacja, dz. cyt., s. 34-35.

64 Por. H.E. Gruber, Rozwiazywanie konfliktów a twórczość. Rola punktu widzenia, w: Rozwiazywanie konfliktów..., dz. cyt., s. 355-361.

65 Por. Ch. W. Moore, Mediacje..., dz. cyt., s. 21-23; R.J. Fisher, Konflikt międzygrupowy, w: Rozwiazywanie konfliktów..., dz. cyt., s. 184. 
stosowana. W pierw jednak warto przełamać tabu i działać na rzecz zmiany podejścia środowisk uczelnianych do konfliktów (z negatywnego, destrukcyjnego i biernego na pozytywne, konstruktywne i kreatywne).

Współczesny uniwersytet powinien być nastawiony na innowacje, dążyć do doskonałości i w sposób systematyczny dbać o osiąganie kolejnych poziomów dojrzałości organizacyjnej. Konieczność zmian w modelu sprawowania władzy na uniwersytetach, $m$.in. poprzez usprawnienie rozwiązywania sporów, jest warunkiem koniecznym dla wzrostu jakości kształcenia i badań naukowych w polskich uczelniach, doskonale wpisuje się także w ideę budowania uniwersytetu nastawionego na rozwój ${ }^{66}$. Tradycyjnie stosowane metody, takie jak np. odpowiedzialność dyscyplinarna, powinny być uzupełnione o nowe sposoby eliminowania negatywnych zjawisk z polskiego życia naukowego. Wymierzenie sankcji nie zawsze rozwiązuje rzeczywisty problem $^{67}$. Konstruktywne podejście do konfliktów organizacyjnych służy np. zwiększeniu motywacji członków organizacji (kształtowanie aspiracji, potrzeb, celów zawodowych i życiowych), stymulowaniu rozwoju przez poszukiwanie nowych rozwiązań starych problemów, a także kształtowaniu lepszych relacji wewnątrz organizacji (tolerancja, cierpliwość, umiejętność słuchania, wyrozumiałość $)^{68}$.

Jeśli chodzi o wnioski praktyczne, najważniejszy wydaje się postulat tworzenia na uniwersytetach „systemów wczesnego ostrzegania” przed problemami organizacyjnymi, aby można było się nimi zająć już po pojawieniu się pierwszych ich symptomów. Tego typu „dyskretny monitoring” w każdej uczelni powinien obejmować przedstawicieli władz, kadrę naukową, personel administracyjny oraz studentów i doktorantów. Nie można przy tym doprowadzać do stygmatyzowania osób, które zgłaszają problem i zwracają się o pomoc, z drugiej zaś strony trzeba wystrzegać się silnych ingerencji w życie akademickie tam, gdzie najpierw nie dano zaangażowanym podmiotom szansy na samodzielne wypracowanie rozwiązania ${ }^{69}$. Warto dbać także o: precyzyjne warunki wymagań i ścieżki rozwoju dla studenta; system

66 Por. M. Geryk, Przywództwo na trudne czasy, czyli rzecz o odpowiedzialnych menedżerach uczel$n i$, w: Zarzq̨dzanie szkoła wyższq, red. J. Dworak, Wyższa Szkoła Bankowa w Gdańsku, Warszawa 2013, s. 47; T. Wawak, Uniwersytet na rozdrożu, dz. cyt., s. 27.

67 Por. M. Czapski, Mediacja w sporach akademickich, dz. cyt., s. 279-28o.

68 Por. A. Wajda, Organizacja i zarzadzanie, dz. cyt., s. 260.

69 Por. T. Marcysiak, Zarzq̨dzanie retencją studentów - perspektywa socjologiczna, w: Zarządzanie szkoła wyższa, dz. cyt., s. 35 . 
wsparcia studentów nie tylko w obszarze edukacji, ale też w obszarze osobistym i zawodowym; systematyczne informacje zwrotne przekazywane od studentów do wykładowców; zaangażowanie w życie akademickie i integrację całej społeczności ${ }^{70}$.

Drugim wnioskiem praktycznym jest prowadzenie systematycznych szkoleń dla członków społeczności akademickiej w zakresie: komunikacji interpersonalnej, dynamiki konfliktów, negocjacji oraz mediacji ${ }^{71}$. Również i władze uczelni powinny dbać o swój rozwój w tym zakresie: „Refleksja na temat siebie samego, sposobu, w jaki radzę sobie z konfliktami, jest niezbędna do ciągłego doskonalenia się i unikania starych nawyków, wrażliwych punktów, presji społecznej itp., które powodują, że wycofujesz się do mniej konstruktywnych sposobów rozwiązywania konfliktów"72.

Najpopularniejszymi strategiami ukierunkowanymi na rzeczywiste rozwiązanie problemu - a nie władcze rozstrzygnięcie sporu - są negocjacje i mediacje. Metody te służą skutecznemu rozwiązywaniu problemów w dużych organizacjach ${ }^{73}$. Są one szybkie i relatywnie tanie, przede wszystkim jednak pozwalają $\mathrm{w}$ dużej mierze opanować napięcie emocjonalne stron ${ }^{74}$. Postępowanie mediacyjne jest oparte na modelu na modelu współdziałania (win/win), przez co zachęca uczestników do samodzielnego poszukiwania rozwiązań. Strony rozmów polubownych są najczęściej zadowolone i dotrzymują dobrowolnie zawartego porozumienia ${ }^{75}$. Ze względu na zasadę dobrowolności możliwość wprowadzenia takich form jak mediacja do praktyki funkcjonowania uczelni jest $\mathrm{w}$ dużej mierze uwarunkowania nastawieniem samych członków społeczności akademickiej ${ }^{76}$. Mediacji nie należy też postrzegać jako „leku na całe zło” polskich uniwersytetów, gdyż nie jest to metoda gwarantująca stuprocentową skuteczność we wszystkich sytuacjach. Na obniżenie poziomu skuteczności mediacji wpływać mogą zaś takie czynniki jak np. wysoki poziom eskalacji konfliktu, brak motywacji stron do uzyskania porozumienia, niskie zaangażowanie $\mathrm{w}$ proces mediacyjny, usztywnienie stanowisk stron czy wyraźnie nierówna siła stron ${ }^{77}$. Oprócz dążenia do

70 Por. T. Marcysiak, Zarządzanie retencją studentów..., dz. cyt., s. 32-33.

Por. M. Deutsch, Wspótpraca i rywalizacja, dz. cyt., s. 38.

Por. K. Kressler, Mediacje, dz. cyt., s. 521. 
„naprawienia” lub przynajmniej „ocieplenia” relacji pomiędzy skłóconymi jednostkami lub grupami mediacja ma też funkcję edukacyjną - jako przykład praktycznego zastosowania takich wartości jak: wzajemny szacunek, dialog czy społeczeństwo otwarte ${ }^{78}$. Dlatego prawdą jest, że „nie ma lepszego niż akademia miejsca do rozwiązywania problemów za pomocą dia$\operatorname{logu}{ }^{79}$. Nie bez powodu mediacje uczelniane rozwijają się w wielu zagranicznych ośrodkach akademickich: „Dziś każda szanująca się amerykańska uczelnia posiada jednostkę - w postaci pracowni, zespołu mediatorów czy ośrodka, zajmującą się rozwiązywaniem sporów akademickich m.in. za pomocą mediacji i facylitacji" ${ }^{80}$. Biorąc pod uwagę opisane w niniejszym artykule uwarunkowania funkcjonowania uniwersytetów, można stwierdzić, że wprowadzenie skutecznych metod diagnozowania i rozwiązywania konfliktów jest niezbędne dla podniesienia jakości kształcenia i pracy naukowej w Polsce.

\section{Bibliografia}

1. Czapski M., Mediacja w sporach akademickich, w: Mediacje. Teoria i praktyka, red. E. Gmurzyńska, R. Morek, Wolters Kluwer, Warszawa 2009, s. 275-288.

2. Deutsch M., Wspótpraca irywalizacja, w: Rozwiązywanie konfliktów. Teoria ipraktyka, red. M. Deutsch, P. T. Coleman, tłum. M. Cierpisz, M. Kodura, G. Kanas, A. Kurtyka, Wydawnictwo Uniwersytetu Jagiellońskiego, Kraków 2005, s. 21-40.

3. Dyląg A., Rosiński J., Niezbędnik dla uczestników sporów, czylijak zyćw świecie konfliktów, w: Rozwiązywanie konfliktów. Teoria i praktyka, red. M. Deutsch, P. T. Coleman, tłum. M. Cierpisz, M. Kodura, G. Kanas, A. Kurtyka, Wydawnictwo Uniwersytetu Jagiellońskiego, Kraków 2005, s. XIII-XV.

4. Fisher R.J., Konflikt międzygrupowy, w: Rozwiązywanie konfliktów. Teoria iprakty$k a$, red. M. Deutsch, P. T. Coleman, tłum. M. Cierpisz, M. Kodura, G. Kanas, A. Kurtyka, Wydawnictwo Uniwersytetu Jagiellońskiego, Kraków 2005, s. 166-184.

5. Geryk M., Przywództwo na trudne czasy, czyli rzecz o odpowiedzialnych menedżerach uczelni, w: Zarzadzanie szkoła wyższa, red. J. Dworak, Wyższa Szkoła Bankowa w Gdańsku, Warszawa 2013, s. 41-50.

78 Por. M. Czapski, Mediacja w sporach akademickich, dz. cyt., s. 284.

79 M. Czapski, Mediacja w sporach akademickich, dz. cyt., s. 275.

8 o M. Czapski, Mediacja w sporach akademickich, dz. cyt., s. 285. 
6. Gruber H.E., Rozwiąywanie konfliktów a twórczość. Rola punktu widzenia, w: Rozwiazywanie konfliktów. Teoria i praktyka, red. M. Deutsch, P. T. Coleman, tłum. M. Cierpisz, M. Kodura, G. Kanas, A. Kurtyka, Wydawnictwo Uniwersytetu Jagiellońskiego, Kraków 2005, s. 341-361.

7. Hatch M.J., Teoria organizacji, tłum. P. Łuków, Wydawnictwo Naukowe PWN, Warszawa 2002.

8. Jachnis A., Psychologia organizacji. Kluczowe zagadnienia, Difin, Warszawa 2008.

9. Jóźwiak J., Tradycyjne koncepcje instytucji akademickiej, w: Model zarzadzania publiczna instytucja akademicka, red. J. Woźnicki, Instytut Spraw Publicznych, Warszawa 1999, s. 15-22.

10. Kisiel A., Bariery komunikacyjne na uczelni akademickiej oraz sposoby ich pokonywania, w: Wyzwania zarządzania jakością w szkołach wyższych, red. T. Wawak, Wydawnictwo Uniwersytetu Jagiellońskiego, Kraków 2011, s. 159-176.

11. Kożuch B., Zmiany zachowań organizacyjnych pod wptywem oczekiwań interesariuszy uczelni akademickich, w: Wyzwania zarządzania jakościa w szkołach wyższych, red. T. Wawak, Wydawnictwo Uniwersytetu Jagiellońskiego, Kraków 2011, s. 49-64.

12. Kressel K., Mediacje, w: Rozwiazywanie konfliktów. Teoria i praktyka, red. M. Deutsch, P. T. Coleman, tłum. M. Cierpisz, M. Kodura, G. Kanas, A. Kurtyka, Wydawnictwo Uniwersytetu Jagiellońskiego, Kraków 2005, s. 519-543.

13. Maliszewski T., Jak wykreowaćsukces uczelni. Budowanie przewagi konkurencyjnej na rynku edukacyjnym, Wolters Kluwer, Warszawa 2015.

14. Marcysiak T., Zarządzanie retencją studentów - perspektywa socjologiczna, w: Zarządzanie szkoła wyższa, red. J. Dworak, Wyższa Szkoła Bankowa w Gdańsku, Warszawa 2013, s. 27-40.

15. Masłyk-Musiał E., Społeczeństwo i organizacje. Socjologia organizacji izarządzania, Wydawnictwo UMCS, Lublin 1996.

16. Mizera K., Kodeksy etyczne na gruncie środowisk akademickich, w: Zarzadzanie szkoła wyższa, red. J. Dworak, Wyższa Szkoła Bankowa w Gdańsku, Warszawa 2011, s. 373-384.

17. Moore Ch. W., Mediacje. Praktyczne strategie rozwiazywania konfliktów, tłum. A. Cybulko, M. Zieliński, Wolters Kluwer, Warszawa 2009.

18. Oleksyn T., Uniwersytet wczoraj i dziś, w: Edukacja uniwersytecka a oczekiwania społeczne, red. E. Okoń-Horodyńska, J. F. Jacko, I. Maciejowska, Wydawnictwo Uniwersytetu Jagiellońskiego, Kraków 2017, s. 57-98.

19. Sikorski Cz.,Język konfliktu. Kultura komunikacji społecznejw organizacji, Wydawnictwo C.H. Beck, Warszawa 2005. 
20. Sułkowski Ł., Kultura akademicka. Koniec utopii?, Wydawnictwo Naukowe PWN, Warszawa 2016.

21. Ustawa z dnia 20 lipca 2018 r. Prawo o szkolnictwie wyższym i nauce, Dz. U. z 2018 r. poz. 1668 z późn. zm., http://prawo.sejm.gov.pl/isap.nsf/download.xsp/WDU20180001668/U/D20181668Lj.pdf (dostęp: 27.08.2020).

22. Wajda A., Organizacja i zarządzanie, Polskie Wydawnictwa Ekonomiczne, Warszawa 2003.

23. Wawak T., Uniwersytet na rozdrożu, w: W poszukiwaniu Uniwersytetu idealnego, red. T. Wawak, J.F. Jacko, Wydawnictwo Uniwersytetu Jagiellońskiego, Kraków 2016, s. 15-30.

24. Wieczorek J., Mediator akademickijako przeciwdziałanie mobbingowi wśrodowisku akademickim, Niezależne Forum Akademickie, Kraków 2009. 
